\title{
Gallbladder Adenocarcinoma, Gastric Foveolar Type
}

National Cancer Institute

\section{Source}

National Cancer Institute. Gallbladder Adenocarcinoma, Gastric Foveolar Type. NCI

Thesaurus. Code C96916.

An unusual, well differentiated adenocarcinoma that arises from the gallbladder. It is characterized by the presence of tall malignant columnar cells with mucin-containing cytoplasm and basally located nuclei. 